\title{
Konseling Sebaya untuk Meningkatkan Perilaku Prososial Siswa
}

\author{
Silvia Yula Wardani \\ IKIP PGRI Madiun \\ Jl. Setia Budi No.85, Kartoharjo, Madiun, Jawa Timur, \\ Indonesia \\ Email: via.ardhanie@gmail.com
}

\author{
Rischa Pramudia Trisnani \\ IKIP PGRI Madiun \\ Jl. Setia Budi No.85, Kec.Kartoharjo, Madiun, Jawa \\ Timur, Indonesia \\ Email: rischa_pramudia@yahoo.com
}

\begin{abstract}
This study aims to determine the effectiveness of peer counseling to increase prosocial behavior of students of SMP Negeri 8 Madiun. The research design study is pre-experimental design. The research subject was eight students taken through purposive sampling techniques. Data collection instrument used a scale of prosocial behavior. The effectiveness of peer counseling test to increase prosocial behavior of students was analyzed using the Wilcoxon Match Pairs Test formula. The analysis of data shows that the students prosocial average score change was 61 or $36 \%$, from a pretest data average was 85 or $49 \%$, to 146 , or $85 \%$ on average of the posttest data. The results showed that peer counseling is effective to increase prosocial behavior of students of SMP Negeri 8 Madiun. The results of this study can be used as reference material for the guidance and counseling teachers in the preparation of peer counseling program to develop students' prosocial behavior.
\end{abstract}

Keywords: peer counseling, prosocial behavior, pre-experimental design

\begin{abstract}
Penelitian ini bertujuan mengetahui efektifitas konseling sebaya untuk meningkatkan perilaku prososial siswa SMP Negeri 8 Madiun. Desain penelitian yang digunakan pre-experimental design. Subjek penelitian sejumlah delapan siswa yang diambil melalui teknik purposive sampling. Instrumen pengumpulan data menggunakan skala perilaku prososial. Pengujian efektifitas konseling sebaya untuk meningkatkan perilaku prososial siswa dianalisis dengan menggunakan rumus Wilcoxon Match Pairs Test. Berdasarkan hasil analisis data menunjukkan rata-rata perubahan skor prososial siswa sebesar 61 atau 36\%. Rata-rata data pretest sebesar skor 85 atau 49\%, dan pada rerata data posttest sebesar skor 146 atau 85\%. Hasil penelitian menunjukkan bahwa konseling sebaya efektif untuk meningkatkan perilaku prososial siswa SMP Negeri 8 Madiun. Hasil penelitian ini dapat dijadikan bahan rujukan bagi guru bimbingan dan konseling dalam penyusunan program konseling sebaya untuk mengembangkan perilaku prososial siswa.
\end{abstract}

Kata kunci: konseling sebaya, perilaku prososial, pre-experimental design

\section{Pendahuluan}

Manusia adalah makhluk individu dan sosial. Kelebihan manusia sebagai makhluk sosial yaitu kesediaannya memberikan pertolongan dan mengulurkan tangan terhadap keluarga, kelompok atau komunitasnya, bahkan siap menolong orang tidak dikenal dari etnis atau bangsa lain tanpa pamrih. Perilaku menolong menggambarkan manusia sebagai makhluk yang tidak egois dan dermawan, mampu untuk memberikan perhatian yang nyata untuk kesejahteraan orang lain, dan merasa bahwa dirinya mempunyai kemampuan memberikan bantuan pada orang lain.

Zaman sekarang perilaku prososial sangat di perlukan dalam kehidupan bermasyarakat. Perilaku sosial penting dimiliki oleh setiap individu termasuk siswa yang pada masa sekolah menengah pertama. Siswa yang sedang memasuki masa remaja tentunya memiliki permasalahan sosial yang lebih kompleks dibandingkan dengan masa sebelumnya. Hal ini disebabkan karena pada masa remaja individu sudah memasuki dunia pergaulan yang lebih luas dimana pengaruh teman dan lingkungan sosial akan menuntut remaja untuk beradaptasi. Berkenaan dengan permasalahan yang dihadapi, remaja membutuhkan pihak yang yang dapat dipercaya untuk membantu menyelesaikan persoalan tersebut. Dalam hal ini, peran konselor sekolah menempati posisi yang strategis yaitu sebagai rekan atau pendamping siswa dalam menyelesaikan permasalahan mereka. Tugas konselor adalah memberikan layanan individu ataupun kelompok dengan cara mengarahkan konseli untuk memahami dan menghadapi situasi kehidupan sehingga bisa membuat keputusan 


\section{WARDANI DAN TRISNANI}

berdasarkan pemahaman untuk kebahagiaan hidupnya.

Hasil wawancara yang dilakukan terhadap dua orang guru bimbingan dan konseling di SMP N 8 Madiun pada bulan November 2014 diperoleh data tentang permasalahan yang sering terjadi pada siswa adalah kurangnya motivasi belajar siswa, tingkat agresifitas siswa yang cukup tinggi dan kurangnya kepedulian antar siswa. Meskipun demikian tidak semua siswa bersedia untuk berbagi cerita dengan konselor sekolah. Selanjutnya, informasi berdasarkan wawancara terhadap sepuluh siswa kelas VIII di SMP N 8 Madiun pada bulan November 2014, menunjukkan bahwa siswa kurang tahu tentang apa itu bimbingan dan konseling dan hal-hal apa saja yang biasanya dikonsultasikan dalam layanan bimbingan dan konseling. Siswa juga menuturkan bahwa banyak siswa yang takut jika berkonsultasi dengan konselor sekolah.

Kondisi di atas, menandakan bahwa hubungan yang dibangun antara konselor dengan siswa masih membutuhkan komunikasi yang lebih efektif. Hubungan yang harmonis antara konselor dengan siswa dapat menghilangkan sekat yang menghambat siswa untuk berkonsultasi dengan konselor sekolah. Siswa membutuhkan hubungan dan suasana kekeluargaan bukan situasi yang formal. Dengan demikian, hubungan konselor dan siswa yang kurang efektif mengakibatkan siswa cenderung kurang memperdulikan keberadaan layanan bimbingan dan konseling di sekolah.

Terkait dengan berbagai masalah yang telah dipaparkan di atas, penulis mempunyai pemikiran bahwa perilaku prososial siswa SMP Negeri 8 Madiun perlu dikembangkan. Perilaku prososal meliputi perilaku membagi (sharing), kejujuran (honesty), tanggung jawab (responsibility) kerjasama (kooperatif), menyumbang (donating), menolong (helping). Sehingga perilaku prososial sangat penting untuk dimiliki oleh siswa agar menjadi pribadi yang berguna di lingkungan sosialnya. Dengan adanya permasalahan siswa SMP Negeri 8 Madiun mengenai bagaimana meningkatkan hubungan sosial atau perilaku prososial, maka diperlukan suatu program yang bisa melatih keterampilan siswa dalam hal berinteraksi sosial dengan teman sebayanya. Program konseling sebaya bisa menjadi alternatif dalam upaya menciptakan treatment yang tepat untuk memungkinkan remaja dapat berinteraksi sosial secara baik dengan teman sebayanya. Dalam proses kegiatannya konseling sebaya akan memberikan pengetahuan bagaimana remaja itu berkomunikasi dan berinteraksi secara baik dengan sesama. Konseling sebaya lebih mengedepankan keterampilan emosi yang dimiliki oleh seorang konselor sebaya maupun konseli, seperti belajar untuk berempati dengan teman sebaya, menjalin komunikasi yang baik dengan orang lain, berusaha untuk bersikap lebih dewasa daripada orang lain. Siswa yang memiliki perilaku prososial dapat memberikan beragam perspektif yang berbeda pada masalah-masalah sosial dan juga bisa membantu orang lain.

Perkembangan siswa SMP dipengaruhi oleh teman sebaya. Melalui pengaruh teman sebaya siswa dapat belajar mengembangkan perilaku tolong menolong terhadap sesama sehingga perilaku prososial penting untuk dikembangkan pada remaja. Penelitian ini dispesifikkan pada upaya meningkatkan perilaku prososial siswa melalui peran teman sebaya yang dikemas dalam konseling sebaya (peer counseling). Maka, tujuan dari penelitian ini untuk mengetahui efektifitas konseling sebaya dalam meningkatkan perilaku prososial siswa SMP Negeri 8 Madiun. Melalui konseling sebaya, siswa dapat mengasah kompetensi yang dimiliki dan dapat bermanfaat untuk membantu teman yang mengalami permasalahan perilaku prososial.

\section{Kajian Literatur}

\section{Konseling Teman Sebaya (Peer Counseling)}

Salah satu layanan bimbingan konseling yang dapat dimanfaatkan disekolah adalah konseling teman sebaya (peer counseling). Gladding (2009: 7) mendefinisikan konseling adalah suatu aktivitas profesional berjangka waktu pendek, bercirikan komunikasi antarpribadi, berlandaskan pandangan teoritis dan berpedoman pada norma etika dan hukum tertentu, yang memusatkan usaha pada bantuan psikologis kepada seseorang yang pada dasarnya bermental sehat agar dapat mengatasi beraneka ragam masalah berkaitan dengan proses perkembangannya dan situasi kehidupannya. Selanjutnya Santrock (2002: 44) mengemukakan teman sebaya adalah anak-anak atau remaja dengan tingkat usia /tingkat kedewasaan yang sama. Teman sebaya atau peer 


\section{KONSELING SEBAYA, PERILAKU PROSOSIAL}

adalah anak-anak dengan tingkat kematangan atau usia yang kurang lebih sama.

Carr (1981: 3) mengemukakan "Basically peer counseling is a way for students to learn how to care about others and put their caring into practice”. Pada dasarnya konseling sebaya merupakan suatu cara bagi para siswa (remaja) belajar bagaimana memperhatikan dan membantu anak-anak lain, serta menerapkannya dalam kehidupan sehari-hari.

Menurut Suwarjo (2008: 1), secara umum keterampilan konseling dibagi menjadi tujuh macam, yaitu attending, keterampilan empati, keterampilan bertanya, perilaku genuine, ketrampilan konfrontasi, keterampilan merangkum, dan keterampilan pemecahan masalah. Adapun penjelasan dari tujuh keterampilan konseling, yaitu: 1). keterampilan attending, 2) keterlibatan postur tubuh, 3) gerakan tubuh secara tepat, 4) kontak mata, 5) lingkungan yang nyaman.

Dalam pembentukan peer counseling pada remaja, langkah-langkah yang dapat ditempuh seperti yang dikemukakan oleh Suwarjo (2008: 12) ada 3 tahapan yaitu memilih calon peer konselor, memberikan pelatihan, dan mengorganisir pelaksanaan peer counseling. Berikut akan dijelaskan keempat tahapan tersebut: 1) pemilihan calon peer konselor, 2) pelatihan peer konselor, 3) pelaksanaan dan pengorganisasian peer counseling.

\section{Perilaku Prososial}

Perilaku prososial adalah sebuah tindakan moral yang harus dilakukan secara kultural seperti berbagi, membantu seseorang yang membutuhkan, bekerja sama dengan orang lain, dan mengungkapkan simpati (Safaria, 2005:117). Selanjutnya Staub dalam Dayakisni dan Hudaniah, (2006: 212) mengemukakan terdapat beberapa faktor yang mendasari seseorang untuk bertindak prososial, yaitu: 1) self-gain; 2) personal values and norm; 3) empathy. Pearce dan Amato (dalam Rahman: 2013: 222) mencoba menggambarkan perilaku menolong itu dengan membuat taksonomi yang membagi situasi menolong ke dalam tiga dimensi. Ketiga dimensi tersebut adalah:

1. Berdasarkan setting sosialnya, perilaku menolong bisa bersifat terencana dan formal atau spontan dan tidak formal (Planned- formal versus spontaneous-informal). Mengadopsi anak yatim, misalnya, merupakan perilaku menolong yang bersifat terencana dan formal, sedangkan meminjamkan pensil termasuk perilaku yang tidak formal dan tidak direncanakan.

2. Berdasarkan keadaan yang menerima pertolongan, perilaku menolong bisa dikategorikan menjadi perilaku menolong yang bersifat serius atau tidak serius (serious versus not serious). Mendonorkan ginjal merupakan perilaku menolong yang bersifat serius, disbanding dengan perilaku menolong menunjukkan arah jalan.

3. Berdasarkan jenis pertolongannya, perilaku menolong bisa bersifat mengerjakan secara langsung atau tidak langsung (doing-direct versus giving-inderect). Yaitu, menunjuk pada apakah pertolongan tersebut diberikan secara langsung kepada korban atau melalui orang ketiga. Menjadi relawan bencana, misalnya, termasuk perilaku menolong yang sifatnya langsung, sedangkan memberikan sumbangan kepada korban bencana melalui lembaga tertentu termasuk perilaku menolong yang bersifat langsung.

Perilaku prososial merupakan perilaku yang berhubungan dengan orang lain dalam bentuk tolong-menolong yang dapat memberikan manfaat bagi orang lain. Prilaku prososial memiliki sejumlah faktor, faktor tersebut meliputi keuntungan diri, nilai dan norma pribadi, dan adanya empati. Siswa sebagai makhluk sosial sangat perlu memiliki perilaku prososial dalam kehidupan sehari-hari untuk berinteraksi terhadap orang lain.

\section{Metode Penelitian}

Penelitian ini dilakukan di SMP Negeri 8 Madiun yang beralamatkan jalan Pilang Mulya Kota Madiun, Penelitian ini menggunakan pendekatan kuantitatif karena menekankan fenomena-fenomena yang objektif dan dikaji secara kuantitatif. Desain penelitian yang digunakan dalam penelitian ini adalah preexperimental design. Pre-experimental design merupakan eksperimen sungguh-sungguh karena masih terdapat variabel luar yang ikut berpengaruh terhadap terbentuknya variabel dependen. Dalam desain ini hanya terdapat satu 


\section{WARDANI DAN TRISNANI}

kelompok eksperimen dan tidak terdapat kelompok kontrol. Populasi dalam penelitian ini sebanyak 118 siswa kelas VIII. Teknik pengambilan sampel yang akan digunakan adalah porposive sampling, berdasarkan tujuan penelitian yaitu siswa yang memiliki perilaku prososial rendah berjumlah delapan siswa akan dijadikan subjek penelitian atau sampel penelitian.

Teknik pengumpulan data yang digunakan dalam penelitian ini adalah skala psikologis. Skala psikologis dalam penelitian ini berbentuk skala sikap dimana hanya mengukur sikap, maka instrumen penelitian akan lebih menekankan pada pengukuran sikap yaitu prososial siswa. Analisis data kuantitatif ini untuk menguji keefektifan konseling sebaya dalam meningkatkan perilaku prososial siswa, maka teknik analisis data dalam penelitian ini meggunakan Wilcoxon Match Pairs Test.

Dari hasil hitung data dapat dibandingkan dengan indeks tabel wilcoxon. Jika jumlah atau hasil analisis lebih besar dari indeks tabel wilcoxon, maka konseling sebaya dianggap efektif dalam meningkatkan perilaku prososial siswa. Dalam mengambil kesimpulan menggunakan pedoman taraf signifikansi $5 \%$ dengan ketentuan:

1. Ho ditolak Ha diterima apabila $Z$ hitung lebih besar atau sama dengan $\mathrm{Z}$ tabel.

2. Ho diterima dan Ha ditolak apabila $Z$ hitung lebih kecil dari $\mathrm{Z}$ tabel.

\section{Hasil dan Pembahasan}

Penelitian eksperimen ini dilakukan pada sampel sejumlah 8 siswa. Untuk mengetahui gambaran tingkat perilaku prososial siswa sebelum diberikan diterapkannya konseling sebaya dan untuk mengetahui keefektifan konseling sebaya dalam meningkatkan perilaku prososial, maka digunakan analisis kuantitatif. Dalam mendeskripsikan perilaku prososial siswa menggunakan skala prososial. Skala tersebut memiliki 46 item dan rentang skor 1-4, dimana skor tertinggi 4 dan skor terendah 1 . Tabel rentang skor dan kriteria dapat dilihat dari tabel 1
Tabel 1

Skor Pemahaman Karier Siswa

\begin{tabular}{clcc}
\hline No & Kriteria & Skor & Keterangan \\
\hline 1. & SR & $46-73,6$ & $\begin{array}{c}\text { Sangat } \\
\text { Rendah } \\
\text { 2. }\end{array}$ \\
R & $73,7-101,2$ & Rendah \\
3. & S & $101,3-128,8$ & Sedang \\
4. & T & $128,9-156,4$ & Tinggi \\
5. & ST & $156,4-184$ & Sangat \\
& & & Tinggi \\
\hline
\end{tabular}

Data di atas merupakan pedoman pemberian skor pada hasil isian skala perilaku prososial yang diisi oleh siswa. Selanjutnya, deskripsi tingkat perilaku prososial siswa SMP Negeri 8 Madiun sebelum diterapkan konseling sebaya menunjukkan sebagian besar berada pada kriteria rendah. Data secara rinci dapat dilihat pada Tabel 2.

Tabel 2

Tingkat Perilaku Prososial Siswa Sebelum Diterapkan Konseling Sebaya

\begin{tabular}{cccc}
\hline Skor & Kriteria & $\begin{array}{c}\text { Jumlah } \\
\text { Sampel }\end{array}$ & $\%$ \\
\hline $46-73,6$ & $\begin{array}{c}\text { Sangat } \\
\text { rendah }\end{array}$ & 0 & 0 \\
$73,7-101,2$ & Rendah & 7 & 87,5 \\
$101,3-128,8$ & Sedang & 1 & 12,5 \\
$128,9-156,4$ & Tinggi & 0 & 0 \\
$156,4-184$ & Sangat & 0 & 0 \\
& tinggi & & 100 \\
\hline
\end{tabular}

Data selanjutnya mengenai skor sub variabel perilaku prososial sebelum diterapkan layanan konseling sebaya berada pada kategori rendah. Data tersebut secara lebih rinci dapat dilihat pada Tabel 3. 
KONSELING SEBAYA, PERILAKU PROSOSIAL

Tabel 3

Skor Sub Variabel Perilaku Prososial Sebelum Diterapkan Konseling Sebaya

\begin{tabular}{clcc}
\hline No & \multicolumn{1}{c}{ Sub Variabel } & Skor & Kategori \\
\hline 1 & Berbagi & 15 & rendah \\
2 & Sikap terbuka & 15 & rendah \\
3 & Tanggung jawab & 15 & rendah \\
4 & Kerja sama & 15 & rendah \\
5 & Mampu menyumbang & 15 & rendah \\
6 & Dermawan & 16 & rendah \\
7 & Menolong & 14 & rendah \\
8 & Mempertimbangkan hak & 13 & rendah \\
& orang lain & & \\
& Skor rata-rata & 15 & Rendah \\
\hline
\end{tabular}

Data selanjutnya mengenai skor tingkat perilaku prososial setelah diterapkan layanan konseling sebaya diperoleh hasil bahwa sebagian besar skor perilaku prososial siswa mengalami peningkatan, yaitu dari kategori rendah menjadi kategori sedang, tinggi, dan sangat tinggi. Data tersebut secara lebih rinci dapat dilihat pada Tabel 4.

Tabel 4

Tingkat Perilaku Prososial Siswa Setelah Diterapkan Konseling Sebaya

\begin{tabular}{cccl}
\hline \multicolumn{2}{c}{ Diterapkan Konseling Sebaya } & & \\
\hline Skor & Kriteria & $\begin{array}{c}\text { Jumlah } \\
\text { Sampel }\end{array}$ & $\%$ \\
\hline $46-73,6$ & Sangat rendah & 0 & 0 \\
$73,7-101,2$ & Rendah & 0 & 0 \\
$101,3-128,8$ & Sedang & 1 & 12,5 \\
$128,9-156,4$ & Tinggi & 6 & 75 \\
$156,4-184$ & Sangat tinggi & 1 & 12,5 \\
\multicolumn{5}{c}{ Jumlah } & 8 & 100 \\
\hline
\end{tabular}

Data selanjutnya mengenai skor sub variabel perilaku prososial setelah diterapkan layanan konseling sebaya diperoleh hasil bahwa sebagian besar skor perilaku prososial siswa mengalami peningkatan, yaitu dari kategori rendah menjadi kategori tinggi. Data tersebut secara lebih rinci dapat dilihat pada Tabel 5.
Tabel 5

Skor Sub Variabel Perilaku Prososial Setelah Diterapkan Konseling Sebaya

\begin{tabular}{clcc}
\hline No & \multicolumn{1}{c}{ Sub Variabel } & Skor & Kategori \\
\hline 1 & Berbagi & 26 & tinggi \\
2 & Sikap terbuka & 16 & rendah \\
3 & Tanggung jawab & 26 & tinggi \\
4 & Kerja sama & 25 & tinggi \\
5 & Mampu menyumbang & 25 & tinggi \\
6 & Dermawan & 24 & tinggi \\
7 & Menolong & 23 & tinggi \\
8 & Mempertimbangkan hak & 27 & tinggi \\
& orang lain & & \\
$\quad$ Skor rata-rata & 24 & tinggi \\
\hline
\end{tabular}

Hasil analisis menunjukkan terjadi perubahan pada kondisi awal perilaku prososial siswa, ditandai dengan peningkatan skor skala perilaku prososial siswa baik pada skor total maupun skor setiap indikator.

Terjadi peningkatan perilaku prososial siswa antara kondisi awal dan kondisi akhir. Agar lebih mudah dalam melihat perubahan kondisi awal dan kondisi akhir tingkat perilaku prososial siswa dapat dilihat pada Gambar 1.

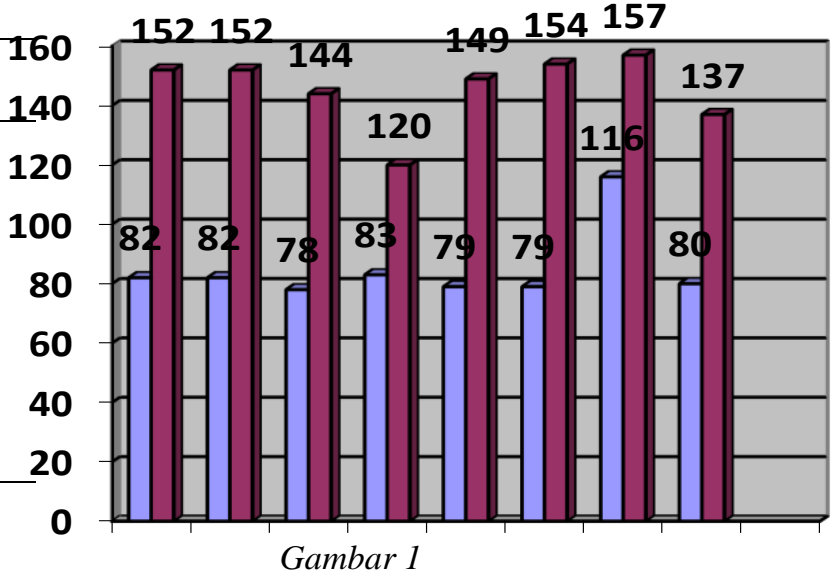

Grafik tingkat perilaku prososial siswa

Gambar 1 menunjukkan bahwa terjadi peningkatan perilaku prososial siswa antara sebelum dan sesudah diberikan konseling sebaya. Rata-rata perubahan yang terjadi adalah sebesar 61 atau sekitar $36 \%$, dari data pretest sebesar 85 atau $49 \%$ menjadi 146 atau $85 \%$. Rata-rata setiap aspek tingkat perilaku prososial siswa sebelum diberi layanan berada pada kategori rendah, setelah diberikan layanan konseling sebaya terjadi 


\section{WARDANI DAN TRISNANI}

peningkatan menjadi kategori tinggi. Ini berarti bahwa konseling sebaya efektif untuk meningkatkan perilaku prososial siswa SMP Negeri 8 Madiun.

Untuk menguji keefektifan konseling sebaya dilakukan dengan teknik statistik parametris, yaitu menggunakan tes ranking bertanda (Wilcoxon Signed Rank Test) dengan menggunakan program SPSS. Wilcoxon Signed Rank Test digunakan untuk menguji signifikasi hipotesis komparatif 2 sampel yang berkorelasi bila datanya berbentuk ordinal dan atau berjenjang (Sugiyono, 2013: 137).

Berdasarkan hasil output tes stastistik diperileh nilai Asymp. Sig (2 tailed) sebesar 0,011 . Karena nilai sig $0,011<0,05$ maka dapat disimpulkan bahwa ada perbedaan tingkat perilaku prososial siswa antara sebelum dan sesudah mendapatkan konseling sebaya, dengan ini maka hipotesis alternatif diterima yang berbunyi "konseling sebaya efektif untuk meningkatkan perilaku prososial siswa SMP Negeri 8 Madiun.

\section{Simpulan}

Hasil penelitian dapat disimpulkan bahwa konseling sebaya efektif untuk meningkatkan perilaku prososial siswa SMP Negeri 8 Madiun. Hasil penelitian ini dapat dijadikan bahan rujukan bagi guru bimbingan dan konseling dalam penyusunan program konseling sebaya untuk mengembangkan perilaku prososial siswa.

\section{Referensi}

Carr, R.A. (1981). Theory and practice of Peer Counseling. Ottawa: Canada Employment and Immigration Commission.

Dayakisni dan Hudaniah, T. (2006). Psikologi Sosial. Yogyakarta: UMM Press.

Gladding, S. T. (2009). Counseling a Comprehensive Profession. London: Pearson Educatin Ltd.

Rahman, Agus Abdul. (2013). Psikologi Sosial. Jakarta: Rajagrafindo Persada.

Safaria, T. (2005). Metode pengembangan Kecerdasan Interpersonal Anak. Yogjakarta: Amara Books.

Santrock, J W. (2002). Life-Span Development. Jakarta: Erlangga.
Sugiyono. (2010). Metode Penelitian Kuantitatif Kualitatif dan $R \& D$. Bandung: Alfabeta.

Sugiyono. (2013). Statistika untuk Penelitian. Bandung: Alfabeta.

Suharsimi Arikunto. (2004). Metode Penelitian. Yogyakarta: Rineka Cipta.

Suwarjo. (2008). Model Konseling Teman Sebaya untuk Pengembangan Daya Lentur (Relicience) Remaja. Makalah Tidak Diterbitkan: Universitas Negeri Yogjakarta.

Suwarjo. (2008). Modul Pelatihan Praktik Keterampilan Konseling. Modul Tidak Diterbitkan: Universitas Negeri Yogyakarta.

Winkel, W. S dan M. M. Sri Hastuti. (2006). Bimbingan dan Konseling di Institusi Pendidikan. Yogyakarta: Media Abadi. 